\title{
E O OSCAR VAI PARA: A CATEGORIA DE MELHOR FILME
}

\author{
And the Oscar goes to: The best Movie Category \\ Y Oscar va a: La mejor Categoria de Cine
}

\author{
Lucas Jorge Garcia \\ Doutorando em Design - UNESP \\ lginfinito@gmail.com \\ Nirave Reigota Caram \\ Dra. Em Educação Escolar - UNISAGRADO \\ nira_rc@hotmail.com
}

\section{Resumo}

O artigo apresenta um estudo a cerca do evento hollywoodiano Oscar, que anualmente realiza uma cerimônia de premiação para diversas categorias relacionadas ao contexto cinematográfico, especialmente a categoria de "melhor filme" que evidencia a indicação dos filmes favoritos ao prêmio. O objetivo tende a compreender a dinâmica e indicação para a categoria de melhor filme, percorrendo as características e causalidade para determinar o melhor filme do ano. Através de uma pesquisa exploratória possibilita conhecer a estrutura do Oscar e o sistema de votação da Academia de Artes e Ciências Cinematográficas, bem como estudar o método comparativo de Durkheim (2007) e a interpretação da análise crítica de audiovisual por Lipovetsky (2002), aplicado às críticas dos filmes vencedores (Hamlet, Titanic e Moonlight) para chegar ao resultado que sugerem que as obras cinematográficas possuem variáveis comparativas de causalidade, estrutura técnica da linguagem audiovisual e sentido cênico discursivo. Assim, o artigo considera que estes elementos comparados, presentes nas obras analisadas, sofrem influência do sistema e da opinião dos membros da Academia, que muitas vezes traz subjetividade nas indicações.

Palavras-chave: Cinema. Oscar. Melhor Filme.

\begin{abstract}
The article presents a study about the Hollywood event Oscar, which annually holds an award ceremony for various categories related to the cinematographic context, especially the category of "best film" that highlights the nomination of favorite films for the award. The objective tends to understand the dynamics and nomination for the category of best film, covering the characteristics and causality to determine the best film of the year. Through an exploratory research, it allows to know the structure of the Oscar and the voting system of the Academy of Arts and Cinematographic Sciences, as well as to study the comparative method of Durkheim (2007) and the interpretation of the critical analysis of audiovisual by Lipovetsky (2002), applied to the criticisms of the winning films (Hamlet, Titanic and Moonlight) to arrive at the result that suggest that cinematographic works have comparative variables of causality, technical structure of audiovisual language and scenic discursive sense. Thus, the article considers that these compared elements, present in the analyzed works, are
\end{abstract}


influenced by the system and the opinion of the members of the Academy, which often brings subjectivity in the indications.

Key words: Movie Theater. Oscar. Best Movie.

\section{Resumen}

El artículo presenta un estudio sobre el evento de Hollywood Oscar, que celebra anualmente una ceremonia de premiación para varias categorías relacionadas con el contexto cinematográfico, especialmente la categoría de "mejor película" que destaca la nominación de las películas favoritas para el premio. El objetivo tiende a comprender la dinámica y la nominación para la categoría de mejor película, cubriendo las características y la causalidad para determinar la mejor película del año. A través de una investigación exploratoria, permite conocer la estructura del Oscar y el sistema de votación de la Academia de Artes y Ciencias Cinematográficas, así como estudiar el método comparativo de Durkheim (2007) y la interpretación del análisis crítico del audiovisual por Lipovetsky (2002), aplicado a las críticas de las películas ganadoras (Hamlet, Titanic y Moonlight) para llegar al resultado que sugiere que las obras cinematográficas tienen variables comparativas de causalidad, estructura técnica del lenguaje audiovisual y sentido discursivo escénico. Por lo tanto, el artículo considera que estos elementos comparados, presentes en los trabajos analizados, están influenciados por el sistema y la opinión de los miembros de la Academia, lo que a menudo trae subjetividad en las indicaciones.

Palabras clave: Cine. Oscar. Mejor Pelicula.

\section{INTRODUÇÃO}

A indústria cinematográfica que se concentrava nos Estados Unidos, após o domínio da Edison Trust no século XIX, na qual apoderava o mercado com patentes de projetores e câmeras, bem como especialmente o uso da película criada pela Kodak, passou a buscar uma nova forma de satisfazer o comércio local, com produtores independentes no intuito de reduzir custos e implantar a industrialização dos sonhos, que se constituiu no século XX, na Califórnia, a renomada Hollywood.

O cinema hollywoodiano em pouco tempo se tornou um instrumento de transmissão de valores nos EUA, por meio de divulgação de novos astros e estrelas de filmes a partir dos anos trinta (30) que gerou um consumo dessa mídia em uma denominação cultural, que também espalhou por todo o mundo. Anos depois, com o nascimento da televisão, a indústria cinematográfica atravessou um momento em que a produção e distribuição de filmes temiam o seu declínio, e diante disso, Santos (2007) aponta que o cinema mundial precisou se recriar junto às novas mídias onde foi consolidando seu espaço no mercado, com a criação de novos gêneros fílmicos, participação do público e de empresas parceiras, e também eventos voltados ao cinema. 
A Academia de Artes e Ciências Cinematográficas (The Academy of Motion Picture Arts and Sciences) de Los Angeles, Califórnia, desde o ano de 1929, entrega anualmente um prêmio em reconhecimento aos profissionais da indústria cinematográfica mundial, o requisitado The Academy Awards (Prêmio da Academia), popularmente conhecido por OSCAR. Em uma cerimônia formal, transmitida pelo mundo todo, o evento reúne grandes personalidades do cinema, que no decorrer da solenidade vão sendo revelados os melhores em cada categoria, até chegar à tão esperada categoria de melhor filme do ano, conforme The Academy of Motion Picture Arts and Sciences (2019).

Diante disso, quais são as características e a causalidade que determinam a escolha de um filme como sendo o melhor do ano? A categoria de melhor filme sempre é a última a ser apresentada e premiada na cerimônia, e possui um apelo maior que as demais, uma vez que se acredita que o filme escolhido como o melhor, possa ser composto de elementos técnicos e também atributos de cunho pessoal e social, das demais categorias premiadas, que assimila ao processo da apuração do resultado.

Portanto, o artigo tem como objetivo geral compreender a dinâmica e escolha na categoria de melhor filme, e para isso, vê-se necessário, conhecer o evento OSCAR; estudar o sistema de votação da Academia; analisar e classificar os critérios e técnicas de um filme na aprovação de melhor para a categoria.

A defesa se pauta na crescente visibilidade do cinema mundial, que com a premiação do OSCAR, este cenário vem se tornando referência para a indústria cinematográfica, na qual os profissionais do ramo são identificados pelo trabalho desenvolvido que há por trás do filme pronto: "Reconhecemos e defendemos a excelência nas artes cinematográfica e nas ciências, inspirar a imaginação e conectar o mundo através de imagens em movimento" (THE ACADEMY OF MOTION PICTURE ARTS AND SCIENCES, 2019).

A Academia se considera a organização de filmes mais importante do mundo, composta por mais de oito mil homens e mulheres que trabalham no cinema, ou seja, profissionais renomados que têm um currículo de peso para selecionar os indicados e os melhores de cada categoria. E mais, o OSCAR é um dos eventos mais midiáticos do mundo, isso porque faz um ótimo trabalho com as redes sociais e a transmissão ao vivo pela televisão em toda parte do globo.

Os filmes produzidos pelo EUA, de acordo com Santos (2007), são considerados pela sociedade e profissionais em geral, os mais bem desenvolvidos em questões de narrativas 
e técnicas audiovisuais, isso porque o país investe neste mercado há muito tempo como já foi introduzido.

As inovações tecnológicas americanas aplicadas ao cinema compreendem em maiores resultados na proximidade com a realidade mundial, que gera cultura e fortalece a economia do país e consequentemente do mundo, como forma de espelhamento. A maioria dos países considerados ricos, como os Estados Unidos, concentra lucro na indústria cinematográfica e recomenda leis de incentivo, como modo de promover a produção nacional, diz Dávila (2004), da Folha de S. Paulo.

O consumo pelo cinema norte-americano, apresentado pelo Relatório do Desenvolvimento Humano (2004), mostra o poder capitalista do EUA através da cultura no cinema:

De cada dez pessoas que saem de casa para ir ao cinema no mundo inteiro, 8,5 verão um filme dos Estados Unidos. De cada dez habitantes do planeta Terra, um assistiu à produção norte-americana "Titanic" (1997), o filme mais visto de todos os tempos. De cada US\$ 10 que são gastos numa bilheteria de qualquer lugar do globo, US\$ 3,5 vão para Hollywood (RELATÓRIO DO DESENVOLVIMENTO HUMANO, 2004, p. 97).

Os filmes são ótimos geradores de entretenimento e arte, sejam eles produções norteamericanas ou de outros países. A propagação de filmes no Brasil, por exemplo, mostrou que nos últimos cinco anos, a sociedade aderiu uma crescente de $43 \%$ no consumo, e as pessoas estão cada vez mais acompanhando os filmes diretamente das salas de cinemas, com 95\% deles, os quais se identificam com o gênero fílmico, aponta a pesquisa IBOPE MEDIA (2014).

Desses filmes, os mais bem comentados nas mídias, ganham possíveis nomes para as indicações ao OSCAR, e as qualificações são as mais variadas, tudo é questão de gosto do próprio público, mas quem decide mesmo quais filmes serão escolhidos, fica a critério dos membros da própria Academia de Artes e Ciências Cinematográficas, que cerca de um mês e meio antes da cerimônia, divulga a lista dos selecionados para conhecimento público. Infelizmente os critérios adotados pela organização na indicação de qualquer categoria, não são comunicados, e este artigo pretende compreender a importância desse dinamismo por trás dos melhores filmes do OSCAR. 


\section{A HISTÓRIA DO OSCAR: DA CRIAÇÃO A TRANSMISSÃO}

A indústria cinematográfica norte-americana investia muito nas produções hollywoodianas no final dos anos vinte (20), fazendo com que o mercado fosse explorado cada vez mais pelos grandes empresários do ramo, foi então que o chefe do estúdio MetroGoldwyn-Mayer (MGM), Louis B. Mayer, reuniu em sua casa, convidados para um jantar de negócios, onde articularam sobre a criação de uma corporação que privilegiasse a indústria cinematográfica, conforme The Academy Of Motion Picture Arts And Sciences (2019).

Na semana seguinte, no Ambassador Hotel, em Los Angeles, uniram-se para um novo jantar, dessa vez 36 convidados do ramo criativo cinematográfico para entender a proposta de Mayer, e foi então fundada a Academia de Artes e Ciências Cinematográficas (AMPAS) em 1927, cujo intuito era premiar em um único evento atores, diretores, produtores, técnicos e escritores, que eram os cinco ramos da indústria cinematográfica da época.

Mayer em sua biografia comentou sobre a criação dos prêmios: "Descobri que a melhor maneira de lidar [com cineastas] era entregando medalhas para todos eles [...] Se eu lhes dessas taças e prêmios eles se matariam para produzir o que eu queria. Então, eu criei o Oscar" (DICK, 2007, p. 91). Decorreu em outro jantar, este no Crystal Ballroom do Biltmore Hotel, com a primeira organização da Academia, uma reunião para tratar dos objetivos, "entre os temas discutidos naquela noite foi a melhor forma de honrar realizações de filmes divertidas e assim incentivar a excelência em todas as facetas da produção de filmes" (THE ACADEMY OF MOTION PICTURE ARTS AND SCIENCES, 2019).

Decidido por votação do grupo, um troféu majestoso seria o prêmio anual aos vencedores, Cedric Gibbons, diretor de arte da MGM, projetou uma estatueta de um cavaleiro de pé agarrado à espada de um cruzado, em cima de um carretel de filmes. George Stanley, o escultor, prototipou o design em três dimensões: com 35 centímetros e quase 4 quilos, feitas de bronze sólido e banhadas a ouro de 24 quilates.

A estatueta foi nomeada como o Prêmio da Academia, o mérito recebido que foi apelidado por Oscar, no qual uma história popular, sem confirmação do fato, conta que Margaret Henrrick (bibliotecária da Academia) observou que a escultura se parecia com seu tio Oscar, no qual a Academia passou a adotar o nome a partir de 1940, mas já vinha sendo conhecida como OSCAR desde 1934, por Sidney Skolsky, colunista de Hollywood.

Em 16 de maio de 1929, no Blossom Room do Roosevelt Hotel, Los Angeles, acontecia à primeira cerimônia dos Prêmios da Academia, com 270 pessoas participando do 
banquete. Os convidados e indicados foram convocados três meses de antecedência da celebração, realizada de modo privado e só depois divulgado a público o resultado. Em 1930, o segundo ano do Prêmio da Academia, já havia uma participação dos jornais nessa propagação da lista dos vencedores, na qual era secretamente mantido pela Academia em acordo com os jornais para publicação às 11 horas do dia seguinte à cerimônia.

Este processo sucedeu até 1940, "quando o Los Angeles Times publicou os vencedores em sua edição da noite, prontamente disponível para os hóspedes que chegavam" (THE ACADEMY OF MOTION PICTURE ARTS AND SCIENCES, c2019). Diante disso, a Academia passou a adotar o sistema de envelope selado usado até os dias de hoje. Além dos jornais locais, uma estação de rádio na cidade produzia a transmissão ao vivo do evento.

A exibição pela televisão, só foi começar em 1953, apenas nos Estados Unidos e no Canadá, ainda em preto e branco, e treze anos depois na TV em cores. Desde 1969 a cerimônia é transmitida internacionalmente, no Brasil iniciou-se no ano de 1970, já no ao vivo via satélite. Atualmente, o OSCAR é um dos eventos televisivos mais assistidos do mundo, segundo pesquisa do O GLOBO (2015), o OSCAR em 2014 foi o segundo com maior índice de audiência no mundo, atingindo 43,7 milhões de espectadores em mais de 200 países.

Desde sua criação, o Prêmio da Academia (OSCAR) sofreu muitas mudanças na estrutura e processo do evento, em especial a divulgação dos resultados e sua transmissão ao público, sendo de jornais a envelopes secretos e da cerimônia particular à propagação do ao vivo pelo mundo todo, respectivos.

De acordo com a The Academy Of Motion Picture Arts And Sciences (2019) o ambiente da ocasião sempre foi variável, pelos renomados hotéis do centro de Los Angeles, iniciado no Blossom Room - Roosevelt Hotel, depois alugado uma série de escritórios na Hollywood Boulevard por cinco anos, mudando para o Edifício Taft (a biblioteca para North Gordon Street), anos seguintes para o famoso Teatro Grauman's Chinese por mais dois anos, logo a Academia comprou o prédio do Marquis Theatre na Melrose Avenue, onde unir no grande espaço, os escritórios, a biblioteca e o teatro para a cerimônia.

Em 1969 com a transmissão internacional, a realização foi feita no Pavilhão Dorothy Chandler do Los Angeles Country Music Center, seis anos depois uma nova sede situada na Wilshire Boulevard em Beverly Hills. Em 1990 com a crescente exploração da biblioteca, precisou-se mudar para a esquina da La Cienega, seguindo dez anos depois para a Pickford Center for Motion Picture Study, porém a cerimônia passou a ser situado na sala de espetáculos do Hollywood Boulevard, o Theatre Dolby inaugurado em 2001, onde até então é 
realizada, o local também é atração de óperas, concertos, shows, homenagens e desfiles de moda no resto do ano. Por fim, em 2012 "a Academia anunciou planos para um museu dedicado a imagens em movimento, por estar localizado ao lado do campus do Museu de Arte do Condado de Los Angeles (LACMA) no prédio da Wilshire May Company".

A presidência da Academia também houve uma série de mudanças, inaugurada com Douglas Fairbanks, posteriormente variando entre eles de 1 a 6 anos de mandato, William C. DeMille, MC Levee, Conrad Nagel, J. Theodore Reed, Frank Lloyd, Frank Capa, Walter Wanger, Bette Davis (renunciada), Jean Hersholt, Charles Brackett, George Seaton, George Stevens, BB Kahane (faleceu), Valentine Davies (faleceu), Wendell Corey, Arthur Freed, Gregory Peck, Daniel Taradash, Walter Mirisch, Howard W. Koch, Fay Kanin, Gene Allen, Robert Wise, Richard Kahn, Karl Malden, Robert Rehme, Arthur Hiller, Frank R. Pierson, Sid Ganis, Tom Sherak, Hawk Koch, Cheryl Boone Isaacs e atualmente John Bailey.

\section{ENTENDENDO O SISTEMA DE VOTAÇÃO}

Com tantas modificações na locação e presidência da Academia, algumas conquistas do mercado cinematográfico foram adaptadas ao processo da cerimônia, como a oportunidade de inscrição para os indicados e a ampliação das categorias aos prêmios a partir de 1935. The Academy Of Motion Picture Arts And Sciences (2019), na primeira celebração, em 1929, o comitê da Academia era composto por 7 pessoas que sugeriam os prêmios distribuídos em 12 categorias que contemplavam os cinco ramos da indústria cinematográfica: atores, diretores, produtores, técnicos e escritores, além do melhor filme por eles produzidos.

Com o passar dos anos e a dominação do cenário dessa indústria, a Academia buscou valorizar toda área contemplativa das inovações mercadológicas e científicas do cinema mundial, e hoje possui 24 categorias comemorativas presentes em três níveis: principais, coadjuvantes e técnicas. Nas categorias principais, têm prêmio para: melhor filme, melhor diretor, melhor ator, melhor atriz, melhor ator coadjuvante, melhor atriz coadjuvante, o melhor roteiro original e melhor roteiro adaptado; nas categorias coadjuvantes têm: melhor filme estrangeiro, melhor animação, melhor documentário, melhor curta-metragem, melhor documentário em curta-metragem e melhor animação em curta-metragem; e nas categorias técnicas: melhor direção de arte, melhor figurino, melhor maquiagem, melhor fotografia, melhor edição, melhor efeitos especiais, melhor canção original, melhor trilha sonora, a melhor edição de som e melhor mixagem de som, apresenta Termômetro Oscar (2019). 
Além dessas categorias comemorativas, a cerimônia premia também categorias especiais como: Prêmio Irving G. Thalberg (dedicado a produtores), Oscar Honorário (conjunto da obra) e Científico e Tecnológico (reconhecimento a invenções e descobertas que ajudam a aprimorar a sétima arte). Diante dessa vasta lista de categorias, a Academia trouxe diversos nomes da indústria cinematográfica para fazer parte do seu comitê, e nos dias de hoje, possui mais de 6 mil membros, conforme a ABC - Associação Brasileira de Cinematografia (2018).

Os membros da Academia são profissionais envolvidos com o cinema, ativos ou aposentados, que possuem o direito a indicação para o OSCAR. Entretanto, cada um deles escolhe em conformidade com sua especialidade, ou seja, diretor vota em melhor diretor, ator/atrizes em suas respectivas categorias de atuação, assim por diante, com exceção de melhor filme, no qual todos os mais de 6 mil membros indicam seus favoritos. A ABC (2018) ainda explica que, estes associados são parte do corpo da Academia alguns por terem sido indicados ao Oscar em premiações passadas e/ou por ter recebido o convite de pelo menos dois integrantes da associação.

O Termômetro Oscar (2019) mostra que o processo de seleção para os indicados acontece em três fases. A primeira começa logo depois do término da cerimônia do OSCAR do ano anterior (entre fevereiro e março), até meados de novembro do mesmo ano, neste período há uma expectativa, observação dos especialistas, opiniões do CETI (informações circuladas na mídia sobre determinado assunto, pessoa ou obra), festivais do ramo e também inscrições de interessados.

Para se inscrever na disputa, os filmes necessitam atender aos requisitos: "ser um longa-metragem com mais de 40 minutos de duração e deve ter ficado, no mínimo, sete dias consecutivo em cartaz de um cinema pago. [...] ter formato (ou largura de película) de $35 \mathrm{~mm}$ ou 70mm ou formatos digitais" (The Academy Of Motion Picture Arts And Sciences, 2019, p. 16, tradução nossa).

Após o término das inscrições (no início de outubro), a Academia desenvolve a Reminder List of Eligible Releases (lista de lembretes de lançamentos elegíveis) e envia a todos os membros junto com uma cédula de indicação, tanto para a categoria especializada de cada associado, quanto de melhor filme. Cada membro escolhe apenas cinco indicados por categoria, em ordem de preferência, no prazo de aproximadamente 1 mês, em seguida devolver as cédulas à Academia, explica o Termômetro Oscar (2019). Vale ressaltar que a categoria de melhor filme estrangeiro possui uma comissão especializada para a indicação. 
Desde 1935, a Price Waterhouse Coopers (PWC), uma empresa de contabilidade, é responsável pela contagem dos votos e a lista dos indicados, que tabula as cédulas e garante o sigilo dos resultados até hoje. Nesta altura, já inicia a segunda fase (de novembro a janeiro), onde a empresa apura as indicações e seleciona os 5 nomes mais citados pelos membros em cada categoria e formula uma nova cédula de votação, com exceção da categoria de melhor filme, que pode variar de 5 a 10 indicados, informa Termômetro Oscar (2019).

Essas cédulas são encaminhadas novamente aos associados para que escolham o melhor de cada categoria, e devolvam à Academia no máximo em duas semanas, neste segundo processo de votação, "é permitido que os membros votassem fora do seu ramo de especialidade, mas a comissão geral aconselha a não escolher em área que não têm experiência" (THE ACADEMY OF MOTION PICTURE ARTS AND SCIENCES, 2019, p. 28, tradução nossa).

No mês de janeiro, a Academia faz a divulgação, via coletiva de imprensa, dos cinco indicados para cada categoria (ou até dez para o melhor filme). A Price Waterhouse Coopers tabula os votos dos melhores em cada categoria e mantém em segredo o resultado dos envelopes dourados até a data da cerimônia, tal qual somente dois auditores sabem os nomes dos vencedores de cada categoria, finalizando assim, a terceira fase deste processo (de janeiro até o grande dia do Oscar).

A PWC tem um rigoroso sistema de apuração dos votos conhecido como "método preferencial", explica Nadale (2016), no qual podem tanto ser em cédulas on-line ou em papel, lembrando que a votação não é obrigatória, sendo assim, alguns associados acabam não votando no prazo estipulado. Existem dois segmentos para calcular os indicados, toda categoria presente nos três níveis categóricos (principais, coadjuvantes e técnicas) são o primeiro fragmento, com exceção da classe de melhor filme que se avalia de outro modo, bem como a quantidade de vagas para indicados são sempre 5, e no caso de melhor filme pode variar de 5 a 10.

Na primeira fase do processo de seleção aos indicados, Nadale (2016) mostra que, após receber as cédulas preenchidas pelos membros da Academia, é levado em conta na contagem somente o primeiro nome da lista dos cinco indicados em cada uma das categorias (válido para o primeiro fragmento), logo quanto mais votos determinado candidato receber, maiores suas chances de se tornar um dos cinco indicados. Se por acaso algum candidato monopolizar os votos (tanto para o primeiro fragmento quanto de melhor filme), vê-se o segundo indicado da lista, e assim por diante. 
O método atribuído para o fragmento de melhor filme é apresentado por Nadale (2016) como:

\begin{abstract}
A indicação depende de uma cota determinada de votos, chamada informalmente de "número mágico". A fórmula é a seguinte: o total de votos dividido pelo total de indicações mais um $(+1)[\ldots]$ O número mágico é sempre arredondado para cima [...]. Se um filme for listado no primeiro lugar mais do que a cota +1 , já garantiu uma das dez vagas na categoria de melhor filme. Mas digamos que só três concorrentes consigam essa nota de corte. Então é hora de fazer uma segunda rodada... Agora, as listas cujo primeiro lugar atingiu o número mágico são desconsideradas. [...]. Criase um novo número mágico dividido pela mesma quantidade de vaga +1 . [...]. Se algum novo filme conseguiu esse total de primeiras colocações, garante a indicação. (NADALE, c2016, grifo do autor).
\end{abstract}

Em caso de algum filme que tenha o domínio sobre os votos, Nadale (2016) ainda esclarece:

\begin{abstract}
Mas e se algum filme monopolizar os votos? Rola outro cálculo: qualquer um que superar o número mágico em $20 \%$ "empresta" esse excedente para filmes que não atingiram a meta. [...]. Cada ponto excedente (' $x$ ' e ' $y$ ') é dividido em duas partes. Uma fica com o filme "doador" (x) e outra vai para um "necessitado" (y). Mas a divisão não é meio a meio. A proporção é definida subtraindo o número mágico do total de votos do doador, dividido de novo pelos votos do doador. [...] Esse " $x$ " é multiplicado pelos "n" pontos excedentes. $O$ resultado arredondado para cima é somado aos pontos do doador. [...] O valor " $y$ " restante também é multiplicado por " $n$ ", arredondado para baixo e distribuído para quem precisa dessa colher de chá. Mais rodadas de mudança de número mágico e redistribuição de pontos são feitas até que os votos que podem ser doados acabem (ou até que as dez vagas sejam preenchidas). (NADALE, c2016, grifo do autor).
\end{abstract}

$\mathrm{Na}$ segunda fase do processo de seleção aos indicados, agora já definidos os melhores dentre os escolhidos, a PWC tabula novamente os votos recebidos dos membros, em cada categoria do OSCAR, dessa vez, como o voto é em um só candidato, o sistema de votação torna simples (para o primeiro fragmento), isto é, ganha o título de melhor na sua categoria, o que levar a maioria dos votos absolutos. Novamente para a classe de melhor filme, o cálculo difere e segue o mesmo método da fase anterior até que se tenha $50 \%$ dos votos + 1 para o vencedor, acrescenta Nadale (2016).

Por fim, o Termômetro Oscar (2019) contextualiza que, a Academia aconselha que seus associados tenham assistido aos filmes do ano vigente para indicar e votar, caso contrário que não façam suas escolhas, garantindo assim maior elegibilidade ao processo. 


\section{METODOLOGIA}

A priori, diante de um universo com 90 vencedores do Oscar na categoria de melhor filme (período de 1929 a 2019), precisou-se definir uma amostragem dessa população, cuja finalidade foi encontrar parâmetros que atinjam os objetivos deste estudo comparativo. As unidades amostrais (elemento da população amostral sobre o qual a medida de interesse é observada) foram definidas através da Amostragem por Julgamento, que conforme Duarte e Barros (2006) selecionam os elementos da amostra de acordo com um determinado perfil estipulado no objetivo da pesquisa, muito utilizado no estudo comparativo, onde as amostras necessitam de maiores correlações viáveis, porém sem generalizar e com diferentes fatores de comparação entre si.

Neste estudo, escolheu-se 3 filmes para serem analisados, são eles: Hamlet (Oscar de 1949), Titanic (Oscar de 1998) e Moonlight (Oscar de 2017), suas escolhas se baseiam puramente em uma amostragem não aleatória: o primeiro filme por ser um clássico do cinema em uma adaptação literária; o segundo filme recordista de indicações ao Oscar com 14, sendo premiado em 11 delas; e o último filme por ser um dos vencedores mais recente até o presente artigo.

Para alcançar tais objetivos e responder a questão norteadora desta investigação, foi necessário realizar uma pesquisa exploratória, identificando informações bibliográficas no âmbito do assunto aqui tratado, com o auxílio de uma revisão de literatura, que de acordo com Duarte e Barros (2006), é o levantamento de dados já estudados por outros autores, que permite fundamentar novos estudos relacionados sobre determinado tema.

Para este, foi indispensável como método o estudo comparativo exposto conforme a teoria durkheiminiana, uma lei de explicação sociológica que evidencia dois passos antecessores ao uso da comparação, apontam Schneider e Schmitt (1998).

O francês sociólogo, antropólogo e cientista político David Émile Durkheim (1858 1917), estudou a sociedade e suas relações de integridade e coerência na modernidade, assim como a utilização do método hipotético-dedutivo na ciência social. Um de seus trabalhos foi "As Regras do Método Sociológico" no qual apresentou o estudo comparativo. Durkheim (2007) introduz a primeira conjectura deste sendo "os fatos sociais tratados como coisas" (p. 31), ou seja, durante a existência externa ao seu pensamento. Todavia, os fatos sociais precisam ser diferenciados dos demais fatos (individuais, psicológicos, gerais e vulgares ao senso comum) para que seja desprovido da vontade do indivíduo que está submetido àquilo que está ao seu redor ou do contexto de determinado conhecimento do objeto de estudo. 
A segunda conjectura da teoria durkheiminiana diz respeito "às relações de causalidade que constituem a essência dos fatos sociais" (DURKHEIM, 2007, p. 32), em outras palavras, explicar de forma sociológica a relação entre os fatos sociais (o todo) com os indivíduos (as partes) que fazem parte desse social, quer dizer, denotar as ligações causais zelando a ordem e o funcionamento da estrutura social. "No estudo dos fatos sociais o cientista deve procurar revelar as causas, orientando-se a partir dos efeitos por elas produzidos" (SCHNEIDER; SCHMITT, 1998, p. 12).

[...] o todo não é idêntico à soma das partes, constitui algo diferente e cujas propriedades divergem daquelas que apresentam as partes de que é composto. [...] A sociedade não é uma simples soma de indivíduos, e sim um sistema formado pela sua associação, que representa uma realidade específica com seus caracteres próprios (DURKHEIM, 2007, p. 20).

Depois de conhecer as duas conjecturas da teoria durkheiminiana, o autor retrata que com essa base fundamental, pode-se chegar ao método comparativo. Para isso, se junta o conteúdo de uma pesquisa científica com a diversidade dos fatos nela inserida, na qual os indivíduos se encontram, e se diferem do outro, denominadas espécies sociais. Cada espécie possui o seu tipo social médio, que nada mais é do que indivíduos com características comuns, ainda que possa ter certas dissemelhanças, como exemplo os mamíferos, que são de espécies diferentes, mas todos mamam, apontam Schneider e Schmitt (1998).

[...] uma vez estabelecida a classificação, a partir deste princípio, não será necessário ter observado todas as sociedades de uma espécie para saber se um fato é geral nessa espécie ou não; a observação de algumas sociedades será suficiente. E mesmo, em muitos casos, bastará uma observação só, mas bem feita, assim como, muitas vezes, uma única experiência bem conduzida chega para o estabelecimento de uma lei (DURKHEIM, 2007, p. 27).

Durkheim (2007) utiliza o processo indutivo pela variação concomitante, ou a correlação de uma variável, a fim de verificar se existe uma lei de explicação por meio de uma causa imutável. Essa causa pode estar presente em duas ocorrências sociais, consequentemente gerar os mesmos efeitos e ter funções parecidas, isso é a concomitância. Para ter como base comparativa a cerca da causalidade "um mesmo efeito corresponde sempre uma mesma causa" (DURKHEIM, 2007, p. 29).

Não temos senão um meio de demonstrar que um fenômeno é causa de outro, e é comparar os casos em que estão simultaneamente presentes ou 
ausentes, procurando ver se as variações que apresentam nestas diferentes combinações de circunstâncias testemunham que um depende de outro (DURKHEIN, 2007, p. 30).

Ainda que possa existir uma margem de erro ao se tratar da complexidade dos fatos sociais, é necessário neutralizar ou controlar esta relação, diante desta realidade, a comparação em estudo se releva:

[...] para que uma variação seja demonstrativa, não é necessário que todas as variações diferentes daquelas que comparamos tenham sido rigorosamente excluídas. O simples paralelismo de valores pelos quais passam dois fenômenos, desde que tenha sido estabelecido num número suficiente de casos bastante variados, é a prova de que existe entre eles uma relação [...] A concomitância constante é, pois, ela mesma, uma lei, seja qual for o estado dos fenômenos que restaram fora da comparação (DURKHEIM, 2007, p. $31)$.

No entanto, a comparação não se ressalta em dois ou mais fatos relacionados com diferenças e semelhanças, é também "demonstrar o princípio de que a cada efeito corresponde uma causa" (SCHNEIDER; SCHMITT, 1998, p. 21). Em sua obra, Durkheim (2007) recomenda três aspectos para se compreender o método comparativo:

(1) O necessário é comparar, não variações isoladas, mas séries de variações regularmente constituídas e, o que é mais, suficientemente extensa, cujos termos se liguem uns aos outros por uma gradação tão contínua quanto possível. Pois as variações de um fenômeno não permitem chegar a uma lei, a não ser que exprimam claramente a maneira pela qual ele se desenvolve em circunstâncias dadas;

(2) Fazendo entrar em linha de conta muitos povos da mesma espécie, dispomos já de um campo de comparações mais vasto. Em primeiro lugar, podemos confrontar a história de um com a de outros e ver se, em cada um deles, tomado à parte, o mesmo fenômeno evoluiu no tempo em função das mesmas condições. Em seguida, podem-se estabelecer comparações entre os diversos desenvolvimentos;

(3) Para explicar uma instituição social pertencente a uma espécie determinada, serão comparadas as formas diferentes que ela apresenta, não apenas entre os povos desta espécie, mas em todas as espécies anteriores. (DURKHEIM, 2007, p. 34 - 36).

Explicar os fatos é o resultado da sociologia comparada, perante a situação de determinada espécie social inserida em um fato na sociedade, de modo a mostrar suas qualificações e interpretar as razões dela estar naquele contexto. 
Quanto à interpretação das informações comparadas, foi feita uma análise crítica por meio do aparato teórico de Lipovetsky (2004), que apresenta três categorias principais: elementos da estória, recursos de narrativa e características de edição, as quais estão exemplificadas ao final da análise a seguir.

\section{ANÁLISE DA CATEGORIA DE MELHOR FILME}

As análises foram realizadas pelas críticas encontradas no Portal Cine Players (2017) na plataforma do Globo.com, onde três membros críticos, Brum (2012), Cunha (2012) e Leal (2017), formados em Cinema, escreveram críticas a cerca dos filmes aqui selecionados, sendo um deles, Cunha (2012) o fundador do próprio Portal.

O Quadro 1 apresenta a análise da crítica de Brum (2012) a respeito do filme Hamlet.

Quadro 1 - Crítica ao filme Hamlet por Brum (2012)

\begin{tabular}{|c|c|}
\hline Contextualização & Fragmento da Crítica \\
\hline $\begin{array}{l}\text { Curiosidade do filme } \\
\text { Hamlet para o Oscar }\end{array}$ & $\begin{array}{l}\text { "[...] é a grande adaptação shakesperiana do cinema (foi o primeiro filme não- } \\
\text { americano a ganhar o Oscar de Melhor Filme, e também o primeiro onde o } \\
\text { vencedor do Oscar de Melhor Ator também era o diretor)" }\end{array}$ \\
\hline $\begin{array}{l}\text { Sobre a obra literária de } \\
\text { Shakespeare }\end{array}$ & $\begin{array}{l}\text { "Certamente, quando uma obra é consagrada em sua mídia original, maior é o nível } \\
\text { de cobrança e exigência e menor a tolerância em relação às liberdades poéticas da } \\
\text { obra original." }\end{array}$ \\
\hline $\begin{array}{l}\text { Adaptação } \\
\text { cinematográfica }- \text { da } \\
\text { literatura para } \mathrm{o} \\
\text { audiovisual }\end{array}$ & $\begin{array}{l}\text { "[...] Olivier tomou em relação ao texto original - como alterar o texto de um } \\
\text { monólogo, cortar falas, omitir personagens (notadamente Fortinbras, Rosencrantz e } \\
\text { Guildenstern) - com a justificativa de cortar os elementos políticos e favorecer o } \\
\text { aprofundamento psicológico do texto original (além de, é claro, reduzir a longa } \\
\text { duração da peça para um filme de duas horas e meia) e sugerir uma forte relação } \\
\text { edipiana entre o protagonista Hamlet, príncipe da Dinamarca, e sua mãe, a rainha } \\
\text { Gertrude." } \\
\text { "[...] a obra de Olivier, ainda que falha como adaptação, é grande como cinema, } \\
\text { marcando essa como uma das poucas obras que conseguem transportar o senso } \\
\text { único de tragédia do dramaturgo para as telas." } \\
\text { "Com as críticas políticas sobre traição e conspiração no mundo da nobreza limada, } \\
\text { concentrou-se afinal no lado atemporal de Hamlet, e o que há de melhor nas peças } \\
\text { de Shakespeare - o lado emocional." }\end{array}$ \\
\hline $\begin{array}{lr}\text { Estrutura técnica da } \\
\text { linguagem audiovisual e } \\
\text { sentido } \\
\text { discursivo }\end{array}$ & $\begin{array}{l}\text { "Laurence Oliver erigiu uma obra perturbadora fortemente marcada por interiores } \\
\text { imensos e escuros, buscando uma sondagem psicológica através de uma expressão } \\
\text { exterior poucas vezes igualada [...] Dá para se perder naqueles corredores } \\
\text { comprimidos onde as paredes têm ouvidos e traições e assassinatos são tramados à } \\
\text { boca pequena." } \\
\text { "Enquanto as câmeras movem-se, câmeras focam e desfocam, profundidades de } \\
\text { campo são amplificadas e distorcidas, imensos corredores são revelados e o castelo } \\
\text { onde habita a Corte da Dinamarca torna-se um lugar quimérico, pertencente à } \\
\text { ordem dos sonhos, onde se dispensa qualquer tipo de verossimilhança em nome da } \\
\text { expressão - é o fantasma do pai (um espectro de voz grave cujo rosto não se vê e } \\
\text { inunda os ambientes onde materializa-se por meio de nuvens de fumaça e distorções } \\
\text { espaciais por meio de truque de luz) que avisa Hamlet de quem foi seu assassino, } \\
\text { seu tio e novo rei Claudius, e o incumbe da missão de fazer justiça." } \\
\text { "[...] Após interpretar a concretização da vingança de Hamlet em um salto } \\
\text { acrobático sobre Claudius, o ator finalmente faz aquele personagem imponente } \\
\text { enfraquecer e tornar-se frágil o suficiente, através dos jogos de posições e }\end{array}$ \\
\hline
\end{tabular}




\begin{tabular}{|c|c|}
\hline & $\begin{array}{l}\text { angulações de câmera e da decomposição da postura corporal para tornar-se o } \\
\text { 'Doce Príncipe'.” } \\
\text { "[...] O filme termina num fatalismo suspense, sem projetar nada para o futuro. O } \\
\text { trono real está vazio, não há substitutos e as emoções humanas, mais uma vez, } \\
\text { ignoram qualquer traço do que parece descrever as últimas palavras do falecido } \\
\text { príncipe da Dinamarca: 'e o resto é silêncio'." }\end{array}$ \\
\hline Protagonista (Hamlet) & $\begin{array}{l}\text { "A interpretação de Olivier para as telas é menos frágil e melancólica (da forma } \\
\text { popularizada pelo teatro vitoriano) e mais perturbada e imponente. Sua atuação é } \\
\text { febril e firme para encarnar um personagem cujo lado vingativo e arrogante era } \\
\text { ainda mais presente." } \\
\text { "[...] traído pela mãe, passa a desconfiar de todas as mulheres e acaba caindo na } \\
\text { loucura e no suicídio." }\end{array}$ \\
\hline $\begin{array}{l}\text { Rivalidade } r \text { de } \\
\text { personagens (Hamlet } \mathrm{e} \\
\text { Claudius) }\end{array}$ & $\begin{array}{l}\text { "[...] intimidadores, duros, paranoicos e arrogantes homens ao longo da trama. } \\
\text { Hamlet e Claudius têm suas facetas de meninos mimados disputando por um lugar } \\
\text { ao lado do trono da rainha." }\end{array}$ \\
\hline Outros personagens & $\begin{array}{l}\text { "Rainha Gertrude }[\ldots . .] \text { inocente que não tem noção do mal que a cerca e acaba sendo } \\
\text { vítima da conspiração cruel de Claudius e Laertes contra Hamlet." } \\
\text { "Ophelia [...] perde o pai Polonius, é tratada como prostituta por Hamlet, [...] uma } \\
\text { mulher que jamais tem o amor correspondido pelo príncipe Hamlet, pelo seu pai } \\
\text { Polonius e o irmão Laertes." }\end{array}$ \\
\hline
\end{tabular}

Fonte: Elaborado pelo autor, adaptado de Brum (2012).

O Quadro 2 apresenta a análise da crítica de Cunha (2012) a respeito do filme

Titanic.

Quadro 2 - Crítica ao filme Titanic por Cunha (2012)

\section{Contextualização $\quad$ Fragmento da Crítica}

Curiosidade do filme "Quis o destino que, no ápice da moda inútil do 3D no cinema, uma das maiores Titanic para o Oscar $\quad$ tragédias marítimas da história fizesse cem anos. Oportunidade perfeita para que James Cameron recauchutasse seu Titanic, que por muito tempo foi a maior bilheteria do cinema, e o relançasse em 3D no final de semana que marca o aniversário da tragédia, apresentando o clássico romance vencedor de 11 Oscars a uma nova geração e prometendo uma experiência completamente nova a quem já está familiarizado com a obra." Adaptação
cinematográfica - uma
história baseada em fatos reais

"Refiro-me ao famoso naufrágio [...] Em 1912, Titanic zarpou depois de um ambicioso projeto de construir o maior navio do planeta. Considerado inafundável, ele colidiu contra um iceberg durante sua viagem inaugural entre a Inglaterra e os Estados Unidos, afundando e, sem resgate a tempo, matando mais da metade de sua tripulação."

Estrutura técnica da "[...] pelo menos na sua versão em película, o 3D não impressiona tanto. Lógico que linguagem audiovisual e há planos perfeitos para o uso do recurso, principalmente quando o navio está sentido cênico discursivo afundando e sobe em direção à tela, mas, no geral, o resultado final ficou aquém do que se poderia esperar: escuro demais, sem brilho, com cores fracas e desbotadas, chegando a afetar a fotografia original - as cenas de dia, por exemplo, parecem nubladas e lavadas, ao contrário daquele sol invejável invadindo o deque do navio que estamos acostumados a ver na TV".

“[...] mas no geral Titanic não envelheceu um único frame desde que deixou os cinemas, ainda nos anos 90. Teoricamente um filme simples, a força de Titanic está justamente na sua imensa gama de abordagens. Temos o romance clichê (mas contagiante) entre Jack e Rose, o discurso contra o capitalismo (na hora $\mathrm{H}$, todos são iguais), a abordagem histórica (o navio está recriado de forma absolutamente impecável), e os efeitos especiais seguem impressionantes mesmo com o desenvolvimento técnico na área."

"As cenas famosas, [...] sendo uma das mais clássicas delas o primeiro beijo entre Jack e Rose, na ponta do navio, tudo embalado por versões da chorosa música interpretada por Celine Dion." 


\begin{tabular}{|l|l|}
\hline $\begin{array}{l}\text { Protagonistas } \\
\text { (Jack e Rose) }\end{array}$ & $\begin{array}{l}\text { "Jack (Leonardo DiCaprio), um jovem de terceira classe, e Rose (Kate Winslet), } \\
\text { uma jovem falida da classe alta do navio que está noiva de um milionário, ainda que } \\
\text { não o ame, afim de salvar o status da sua família." }\end{array}$ \\
\hline
\end{tabular}

Fonte: Elaborado pelo autor, adaptado de Cunha (2012).

O Quadro 3 apresenta a análise da crítica de Leal (2017) a respeito do filme Moonlight.

Quadro 3 - Crítica ao filme Moonlight por Leal (2017)

\begin{tabular}{|c|c|}
\hline Contextualização & Fragmento da Crítica \\
\hline $\begin{array}{l}\text { Curiosidade do filme } \\
\text { Moonlight para o Oscar }\end{array}$ & $\begin{array}{l}\text { "[...] a publicidade o vende como uma problemática identitária (não só uma, mas a } \\
\text { melhor do ano) espetacular". } \\
\text { "Se a sexualidade, as drogas, a prostituição e a criminalidade propulsionam tal } \\
\text { moldura identitária, é mais provável que Moonlight se instale na beira de um } \\
\text { abismo. De um lado, a história que se conta de maneira quase sádica: qualquer } \\
\text { clarão "vaga-lumesco" de felicidade é castrado, e acredita-se que intencionalmente, } \\
\text { por uma constelação de misérias. Do outro lado, a aproximação quase inelutável da } \\
\text { obra que tangencia demais o tecido social e para quem será impossível } \\
\text { desvencilhar-se do puro veículo: 'vejam bem, a vida desses americanos é uma } \\
\text { penúria'." }\end{array}$ \\
\hline $\begin{array}{l}\text { Relação com o mundo } \\
\text { do preconceito } \\
\text { imposição social }\end{array}$ & $\begin{array}{l}\text { "Ainda infante, impõem-lhe uma sexualidade que ele não pode compreender, } \\
\text { apercebe-se de um mundo de tráfico prematuramente, num ricochetear de traição: a } \\
\text { droga que rouba a sanidade e o carinho que sua mãe podia oferecer é vendida pelo } \\
\text { único amigo que acredita ter feito, homem décadas mais velho que ele e } \\
\text { supostamente mais experiente. Já adolescente, o horror da sexualidade que não pode } \\
\text { explorar se intensifica." } \\
\text { "Colocar um personagem já sofrido diante de um confronto final com a mãe, só } \\
\text { para fazê-la regurgitar e atestar a via-crúcis." }\end{array}$ \\
\hline $\begin{array}{lr}\text { Estrutura técnica da } \\
\text { linguagem audiovisual e } \\
\text { sentido } & \text { cênico } \\
\text { discursivo } & \end{array}$ & $\begin{array}{l}\text { "Sua trajetória narrativa se divide por tripartição clássica - infância, adolescência, } \\
\text { idade adulta." } \\
\text { "Sob a luz do luar, o corpo inclina-se para receber o primeiro contato sexual. As } \\
\text { mãos se agarram a areia para controlar o frêmito de prazer. Mas a areia escorrega- } \\
\text { lhe pelos dedos: seu único momento de singeleza apaixonada é sufocado pela } \\
\text { agressividade destrutiva das gangues de escola." } \\
\text { "[...] Assim que abre espaço para a simpatia, derruba-nos novamente. E daí que } \\
\text { aquela vida seja um sucedâneo de injustiças? Tudo se dá na maneira de filmar } \\
\text { (enquadrar ainda não perdeu seu poder de dar significado), de coser o que se conta. } \\
\text { Os gritos da mãe em slow motion, a mistura simbólica do azul do luar com quase } \\
\text { toda a direção de arte, os planos centralizados de rostos em discordância com o } \\
\text { tempo do que está sendo dito - tudo transparece afetação, a tentativa de fazer } \\
\text { sentir." } \\
\text { "E quando finalmente nos instauramos dentro do tempo de uma reconciliação (do } \\
\text { filme e do personagem, por sinal), quando a tensão entre dois corpos e duas } \\
\text { memórias começa a se infiltrar, já não há mais tempo para redenção." }\end{array}$ \\
\hline Protagonista (Chiron) & "Chiron é negro, gay e pobre." \\
\hline
\end{tabular}

Fonte: Elaborado pelo autor, adaptado de Leal (2017).

Em relação à interpretação da crítica de narrativa audiovisual, Lipovetsky (2004) designa que:

a) Elementos de estória: mostra a análise a partir do tema da estória, sobre o "quê é" narrado, observando imagens que são compostas por mensagem para dar sentido ao padrão narrativo. 
HAMLET - Exibe a adaptação de uma obra literária do gênero romântico que busca trazer forte relacionamento dos personagens Hamlet e sua mãe Gertrude, toda a história do envolvimento de acontecimentos da nobreza, em uma perspectiva de Shakespeare com a emoção nos personagens principais. O tio Claudius, a Ophelia e Laertes, contracenam como os personagens secundários da trama, para acrescentar dramatização dentro na narrativa. A Corte da Dinamarca ambienta a função de situar o local onde a estória ocorre, bem como os corredores sombrios motiva as ações de Hamlet na jornada da descoberta do assassinato de seu pai.

TITANIC - Uma viagem inaugural ao novo e maior navio do planeta, que colide com um iceberg e afunda. O romantismo da obra retrata a história real do navio Titanic e principalmente o relacionamento entre os personagens principais Jack e Rose. Os personagens secundários, noivo de Rose, capitão do navio e a família de Rose, aparecem em segundo plano para complementar a narrativa, que se passa no interior do navio.

MOONLIGHT - Uma história de sofrimento de Chiron, um garoto negro, gay e pobre, contada em três etapas da vida do personagem principal. A narrativa mostra um cenário de Miami, repleto de criminalidade, prostituição, drogas e sexualidade identitária. Ao observar o outro lado da cidade, Chiron sonha com um futuro melhor.

b) Recursos de narrativa: se atém ao "como é" narrado na estória, em sua construção como todo, que oferece ao espectador possíveis significados implícitos na narrativa.

HAMLET - A noção que o filme passa, aponta para uma mudança de personalidade de Hamlet após a morte do pai, onde passa a ouvir sua voz pelos corredores da corte. A fim de fazer justiça pelo assassinato, o príncipe Hamlet cheio de ódio, se vinga de Claudius, mas acaba se tornando frágil aos poucos, como se o sentimento tomasse conta de si. A perda da confiança em sua mãe e consequentemente nas mulheres ao redor, tornando-o perturbado até cometer o suicídio. Outro recurso da narrativa está dentro do personagem Hamlet, que em todo contexto da estória, proporciona ao espectador um ponto de vista emotivo. Os truques de câmera escura nos corredores do castelo, as nuvens de fumaça com distorções espaciais em truques de luz, uma voz off (do pai) caracterizam o ambiente tenebroso na projeção da descoberta da 
identidade do assassino Claudius. O final do filme manifesta suspense, sem projeção futura e o trono da corte vazio.

TITANIC - A narração parte dos personagens principais, que contam suas vidas e se apaixonam. Diante dos eventos que discorre até o navio afundar, a coragem e o amor dos dois movimenta a estória e meche com a emoção do espectador, especialmente quando sucede o primeiro beijo na ponta no navio. A construção do 3D trouxe uma realidade próxima da tragédia e impacta o receptor a abordagem em cenas românticas, discurso do capitalismo e a própria recriação.

MOONLIGHT - A perspectiva dramática dos eventos da estória contam as dificuldades do personagem, uma sexualidade heterossexual sendo imposta à Chiron na infância, ao redor um mundo de tráfico e traições, principalmente do único amigo. $\mathrm{Na}$ adolescência a sexualidade aflorada e intensificada. Chiron apanhando dos garotos. Um relacionamento conturbado com sua mãe. Na vida adulta, mais dificuldades da pobreza, negritude, homo afetividade e as injustiças sociais.

c) Características de edição: elementos de criação de efeitos computacionais que influenciam a realidade "sobre" a narrativa, compondo e fortalecendo o contexto da estória produzida e propiciando significações da narrativa visual por parte do receptor.

HAMLET - a realidade mostrada no filme retrata o lado sombrio da estória por meio dos recursos de narrativa. Por se tratar de um filme épico, os efeitos especiais não são tão videntes, porém as técnicas de composição das cenas contribuem para que o espectador deduza as ações, especialmente nos sons da voz do pai e o próprio silêncio após a morte de Hamlet.

TITANIC - Embora o 3D não tenha tanta perfeição, as cenas trouxeram impacto para a narrativa. A música interpretada por Celine Dion carrega forte elemento do romantismo entre os personagens principais.

MOONLIGHT - Passagem da vida do personagem para contar uma história trágica e reprimida. $\mathrm{O}$ sofrimento de quem é negro, gay e pobre traz representatividade a questões sociais atuais. A narrativa sob a luz do luar, oferece ao personagem momento de prazer. Os gritos da mãe e a conjunção do azul nas cenas manifesta um sentido emocional. 


\section{RESULTADOS E DISCUSSÕES}

Partindo das críticas discursivas das análises desenvolvidas, cria-se uma linha de raciocínio que estabelece certa relação e também diferenças entre os filmes aqui estudados. A seguir, o Quadro 4 mostra os resultados das comparações diretas e indiretas dos filmes analisados, bem como suas estruturas cinematográficas no audiovisual e discursivo, em cima das críticas estabelecidas.

Quadro 4 - Resultados das comparações e estrutura cinematográfica das obras.

\begin{tabular}{|c|c|c|c|}
\hline & Filme 1 - Hamlet & Filme 2 - Titanic & Filme 3 - Moonlight \\
\hline \multicolumn{4}{|c|}{ Comparações das variáveis dentro da obra cinematográfica } \\
\hline - Diretas & $\begin{array}{l}\text { - Modificação com a } \\
\text { narrativa, uma adaptação } \\
\text { literária para o cinema; } \\
\text { - Autonomia do diretor } \\
\text { em conduzir a obra no } \\
\text { audiovisual, } \\
\text { evidenciando Hamlet e } \\
\text { seu lado emocional, sem } \\
\text { perder a originalidade de } \\
\text { Shakespeare. }\end{array}$ & $\begin{array}{l}\text { - Inovação do cinema } \\
\text { com o 3D nas cenas de } \\
\text { efeitos especiais; } \\
\text { - Cronologia histórica } \\
\text { situando os fatos } \\
\text { sincronizados raos } \\
\text { detalhes do ocorrido em } \\
\text { 1912, na visão } \\
\text { capitalista, romântica e } \\
\text { tecnológica (3D). }\end{array}$ & $\begin{array}{l}\text { - Aproximação com o } \\
\text { público e sua repercussão } \\
\text { social; } \\
\text { - Relação com o mundo } \\
\text { atual do } \\
\text { americano, com um nicho } \\
\text { da sociedade } \\
\text { representada. }\end{array}$ \\
\hline - Indiretas & $\begin{array}{l}\text { - Diretor ser também o } \\
\text { ator principal; } \\
\text { - Fatores psicológicos do } \\
\text { personagem Hamlet para } \\
\text { movimentar a trama e } \\
\text { criar clímax, e também } \\
\text { transformar teatro em } \\
\text { longa de } 2 \mathrm{~h} 30 \mathrm{~min}, \\
\text { através de técnicas } \\
\text { audiovisuais. }\end{array}$ & $\begin{array}{l}\text { - Associação com os } 100 \\
\text { anos do naufrágio do } \\
\text { Titanic; } \\
\text { - Representatividade de } \\
\text { apelo emocional com os } \\
\text { personagens Rose e } \\
\text { Jack, principalmente na } \\
\text { trilha sonora de Celine } \\
\text { Dion, onde os } \\
\text { transformou em } \\
\text { protagonistas, mais que } \\
\text { o próprio Titanic. }\end{array}$ & $\begin{array}{l}\text { - Sexualidade, as drogas, a } \\
\text { prostituição e a } \\
\text { criminalidade nos EUA; } \\
\text { - A caminhada da vida } \\
\text { difícil, relação familiar } \\
\text { posa à prova, anos se } \\
\text { passando, descobertas e } \\
\text { desejos reprimidos, } \\
\text { comportamentos } \\
\text { conduzidos pelo sistema } \\
\text { social. }\end{array}$ \\
\hline \multicolumn{4}{|c|}{ Estrutura técnica da linguagem audiovisual e sentido cênico discursivo } \\
\hline Técnicas & $\begin{array}{l}\text { Cenário e figurino épicos, } \\
\text { iluminação forte com } \\
\text { sombras e fumaça, } \\
\text { movimento de câmera e } \\
\text { enquadramentos para (re) } \\
\text { construção de cenas, } \\
\text { sonoplastia interior e } \\
\text { vozes. }\end{array}$ & $\begin{array}{lr}\text { História acontece num } \\
\text { navio, a estrutura cênica } \\
\text { e narrativa com efeitos } \\
\text { especiais. 3D em } \\
\text { película trouxe na } \\
\text { qualidade: iluminação } \\
\text { sem brilho, escuras, } \\
\text { cores fracas } \\
\text { distorcidas, porém os } \\
\text { planos perfeitos (no } \\
\text { navio afundando em } \\
\text { especial), sonoplastia } \\
\text { externa e interna, com } \\
\text { trilha sonora. }\end{array}$ & $\begin{array}{l}\text { Tripartição clássica } \\
\text { (infância, adolescência e } \\
\text { adulto), diversos cenários } \\
\text { (cômodos da casa, ruas, } \\
\text { escola, praia). Planos bem } \\
\text { enquadrados, maioria } \\
\text { centrais, efeitos como } \\
\text { slow motion, iluminação } \\
\text { aparente (ênfase tom azul } \\
\text { do luar), sonoplastia com } \\
\text { auxílio de vozes. }\end{array}$ \\
\hline Sentido & $\begin{array}{l}\text { Provocar sensação de } \\
\text { suspense e despertar } \\
\text { desejos em Hamlet, bem } \\
\text { como a sua desconstrução }\end{array}$ & $\begin{array}{l}\text { Abordagem romântica } \\
\text { (emocional), capitalismo } \\
\text { à mostra (racional), fato } \\
\text { histórico (descritivo). }\end{array}$ & $\begin{array}{l}\text { Sensação de desejo e } \\
\text { paixão, ao mesmo tempo } \\
\text { com repulsa e ódio. }\end{array}$ \\
\hline
\end{tabular}




\begin{tabular}{|c|c|c|c|}
\hline & da persona. & & \\
\hline Personagens & $\begin{array}{l}\text { - Hamlet: desconfiado, } \\
\text { perturbado, louco, } \\
\text { melancólico, vingativo; } \\
\text { - Claudius: afronta na } \\
\text { mesma arrogância; } \\
\text { - Rainha Gertrude: } \\
\text { inocência em pessoa; } \\
\text { - Ophelia: nunca amada. }\end{array}$ & $\begin{array}{l}\text { - Titanic (o navio): } \\
\text { grandiosidade } \\
\text { econômica; } \\
\text { - Jack e Rose: de classes } \\
\text { sociais distintas, } \\
\text { despertam romance entre } \\
\text { si. } \\
\text { - Milionário: poder e } \\
\text { dinheiro. }\end{array}$ & $\begin{array}{l}\text { - Chiron: negro, gay, } \\
\text { pobre, que sofre calado e } \\
\text { têm emoções e prazeres } \\
\text { escondidos; } \\
\text { - Mãe: protetora, viciada, } \\
\text { descontrolada; } \\
\text { - Homem mais velho: a } \\
\text { experiência. }\end{array}$ \\
\hline
\end{tabular}

Fonte: Elaborado pelo autor

No Quadro 4 foi possível determinar as características dos filmes selecionados classificando em cada filme seus efeitos comparados variáveis na obra e a estrutura técnica e de sentido, mediante aos seus fatos sociais que foram tratados como coisas em seu todo dentro de cada obra cinematográfica. Os três filmes (Hamlet, Titanic e Moonlight) são tipos de espécies sociais para esta pesquisa e cada um possui seu tipo social médio, ou seja, as características comuns embora haja certas dissemelhanças.

A partir dessas análises estabelecidas pelos efeitos, têm-se as causas, que conforme a teoria durkeminiana exposta por Schneider e Schmitt (1998), é às relações de causalidade que constituem a essência dos fatos sociais (Quadro 5).

Quadro 5 - Causalidade nas obras analisadas.

\begin{tabular}{|c|c|c|c|}
\hline & Filme 1 - Hamlet & Filme 2 - Titanic & Filme 3 - Moonlight \\
\hline \multicolumn{4}{|c|}{ Comparação das variáveis } \\
\hline $\begin{array}{l}\text { - } \quad \text { Presente } \\
\text { (semelhança) }\end{array}$ & $\begin{array}{l}\text { - Obras do gênero dran } \\
\text { - Contar história de f } \\
\text { riqueza de detalhes; } \\
\text { - Personagem (s) princi } \\
\text { - Cenografia e figurino } \\
\text { - Trabalho de linguage }\end{array}$ & $\begin{array}{l}\text { precisa, técnica de cr } \\
\text { desenrola o clímax; } \\
\text { ovisual (planos, efeito }\end{array}$ & $\begin{array}{l}\text { ogia sendo objetivo, com } \\
\text { xagens, etc). }\end{array}$ \\
\hline $\begin{array}{l}\text { - Ausente } \\
\text { (diferença) }\end{array}$ & $\begin{array}{l}\text { - Contextualização da } \\
\text { - Aprimorar/Introduzir } \\
\text { - Busca pela representa } \\
\text { - Técnicas de direção d }\end{array}$ & $\begin{array}{l}\text { ca/Enredo } \\
\text { as cinematográficas; } \\
\text { de sociocultural; } \\
\text { e sonoplastia. }\end{array}$ & \\
\hline \multicolumn{4}{|l|}{ Espécie comparativa } \\
\hline $\begin{array}{l}\text { Confrontar histórias e } \\
\text { evolução do fenômeno }\end{array}$ & \multicolumn{3}{|c|}{$\begin{array}{l}\text { As narrativas conduziram o enredo conforme o ideal de cada obra, contanto sua } \\
\text { história de acordo com seus contextos. O clímax foi o ápice dessas histórias, sendo } \\
\text { o ponto chave para encontrar o caminho próximo à realidade do público, através } \\
\text { da associatividade, sem perder-se aos demais fatos sociais, apenas da própria } \\
\text { espécie. Isto se dá pelas emoções dos personagens e toda produção audiovisual } \\
\text { para uma convergência de sentidos. }\end{array}$} \\
\hline
\end{tabular}

\section{Comparação da espécie como toda}

As três obras cinematográficas mostram uma relação com algo inovador na narrativa, podendo utilizar de 
técnicas novas ou ainda atributos que possam conduzir a história a uma nova produção de sentido. Sempre há uma técnica nas linguagens diferente das já conhecidas, um recurso audiovisual novo e/ou mesmo um discurso novo, a fim de contextualizar a narrativa cinematográfica.

Fonte: Elaborado pelo autor

A partir das informações presentes no Quadro 5, se têm a explicação das causas que levaram os filmes Hamlet, Titanic e Moonlight se tornar os melhores filmes e vencedores do Oscar nesta categoria. $\mathrm{Na}$ análise pode verificar comparações individuais das obram estudadas, as quais denotam elementos de comparação, como uma narrativa dramática e romântica, com forte apelo emocional, que gera valor e reflexividade para o espectador.

Prender a atenção durante o filme por meio de um sentido cênico discursivo, onde a narrativa contextualiza as ações dos personagens rumo a um objetivo próprio. O clímax de cada filme retrata sensações de causalidade, como a provocação de suspense e desconstrução da persona em Hamlet, o romantismo e representação de fato históricos em Titanic, o desejo reprimido e simultaneamente o ódio e aversão em Moonlight.

\section{CONSIDERAÇÕES FINAIS}

A premiação do Oscar se tornou ao longo dos anos, um evento que reúne grandes nomes da cinematografia, destacando os melhores segundo a visão dos membros da organização que indicam os possíveis vencedores, depois por meio de um minucioso sistema de votação, aferido pela empresa Price Waterhouse Coopers, se têm os vencedores de cada categoria.

A visibilidade internacional que o evento possui, caracterizada por prestigiar filmes e reconhecer a sétima arte através das indicações e votos dos membros da Academia, indivíduos renomados no ramo cinematográfico, contribui para a valorização da produção audiovisual. A indicação para ser o melhor filme de acordo com o resultado na análise dos filmes vencedores Hamlet, Titanic e Moonlight, se deu por meio de características e causalidade com semelhanças e diferenças, mas que se compreender no mesmo universo da espécie social, no qual a partir dos efeitos geram causas, o que se pode atribuir a uma possível escolha, tendo em vista as relações comparáveis que se observam (Quadro 4 e 5). Características e causalidades estas, respondem ao problema da pesquisa, e, portanto, a escolha de melhor filme se dá pela percepção e proximidade com fatores sociais, pela emoção dramatizada na narrativa das obras cinematográficas analisadas, a verificação do clímax das histórias traz engajamento com o espectador através de sentidos entre contexto da narrativa e a produção audiovisual. 
Vale salientar que a cerca do objetivo desta pesquisa, se compreendeu a dinâmica e escolha na categoria de melhor filme mediante a metodologia de comparação proposta por Durkheim (2007) e a interpretação da análise crítica de audiovisual por Lipovetsky (2002), que analisou e classificou critérios e técnicas na amostragem dos três filmes vencedores na categoria para o entendimento do universo da pesquisa. Por fim, o artigo apresentou uma visão sobre a escolha do melhor filme a partir de um controle de uma linguagem mais técnica estudada na comparação, ainda que muitas escolhas possam ser puramente por gosto ou até mesmo outros fatores, que podem existir dentro da margem de erro da complexidade dos fatos sociais.

\section{REFERÊNCIAS}

ABC. Associação Brasileira de Cinematografia. c2018. Disponível em: $<$ http://abcine.org.br/site/826-2/>. Acesso em 28 mar. 2019.

BRUM, Bernard D. I. Crítica Hamlet. Portal Cine Players. [20 fev. 2012]. Disponível em: <http://www.cineplayers.com/critica/hamlet/2359> Acesso em: 15 mar. 2019.

CUNHA, Rodrigo. Crítica Titanic. Portal Cine Players, [13 abr. 2012]. Disponível em: <http://www.cineplayers.com/critica/titanic/2386> Acesso em: 15 mar. 2019.

DÁVILA, Sérgio. Estudo confirma hegemonia dos EUA no cinema mundial. Folha de S. Paulo. São Paulo. 2004. Disponível em: <http://www1.folha.uol.com.br/fsp/brasil/fc1507200425.htm>. Acesso em: 12 mar. 2019.

DICK, Bernand F. Review: Lion of Hollywood - the life and legendo f Louis B. Mayer by Scott Eyman. Film Quart, Vol. 60, No 3. Spring, 2007. Disponível em:

<http://fq.ucpress.edu/content/60/3/96.2>. Acesso em: 20 mar. 2019.

DUARTE, Jorge; BARROS, Antonio. (Org.). Métodos e Técnicas de Pesquisa em Comunicação. 2. ed. São Paulo: Atlas, 2006.

DURKHEIM, Émile. As Regras do Método Sociológico. 3. ed. São Paulo: Martins Fontes, 2007.

IBOPE MEDIA. Da telona para as telinhas. 2014. Disponível em:

<https://www.kantaribopemedia.com/da-telona-para-as-telinhas-3/>. Acesso em: 12 mar. 2019.

LEAL, Felipe. Crítica Moonlight: sob a luz do luar. Portal Cine Players. [19 jan. 2017]. Disponível em: < http://www.cineplayers.com/critica/moonlight-sob-a-luz-do-luar/3433> Acesso em: 15 mar. 2019.

LIPOVETSKY, G. Os tempos hipermodernos. São Paulo: Editora Barcarolla, 2004.

NADALE, Marcel. Como é a votação do Oscar? Mundo Estranho. 2016. Disponível em:

<https://mundoestranho.abril.com.br/cinema/como-e-a-votacao-do-oscar/>. Acesso em: 21 mar. 2019. 
O GLOBO. O brilho que atrai grandes marcas para o Oscar. 2015. Disponível em:

<https://oglobo.globo.com/economia/o-brilho-que-atrai-grandes-marcas-para-oscar-15407332>.

Acesso em: 20 mar. 2019.

RELATÓRIO DO DESENVOLVIMENTO HUMANO. Liberdade cultural num mundo

diversificado. Lisboa: PNUD. 2004. Disponível em: <http://hdr.undp.org/sites/default/files/hdr2004portuguese.pdf >. Acesso em: 12 mar. 2019.

SANTOS, Rogério. Indústrias Culturais: imagens, valores e consumo. Lisboa, Portugal: Editora 70 Ltda, 2007.

SCHNEIDER, Sérgio; SCHMITT, Cláudia Job. O uso do método comparativo nas Ciências Sociais. Cadernos de Sociologia, Porto Alegre, v. 9, p. 49-87, 1998.

TERMÔMETRO OSCAR. [Análise e Informações Institucionais do site]. c2019. Disponível em: < http://www.termometrooscar.com/>. Acesso em: 27 mar. 2019.

THE ACADEMY OF MOTION PICTURE ARTS AND SCIENCES. Oscar. [Análise e Informações Institucionais do site]. c2019. Disponível em: <http://www.oscars.org/>. Acesso em: 12 mar. 2019.

Oscar. 90TH Annual Academy Awards of Merit. 2019. Disponível em:

<http://www.oscars.org/>. Acesso em: 12 mar. 2019.

Original recebido em: 09 de setembro de 2019

Aceito para publicação em: 07 de junho de 2020

Lucas Jorge Garcia

Doutorando no Programa de Pós-Graduação em Design e Mestre em Mídia e Tecnologia pela Universidade Estadual Paulista "Júlio de Mesquita Filho" (UNESP). Especialista em Cinema e Linguagem Audiovisual pela Universidade Braz Cubas (UBC).

Nirave Reigota Caram

Doutora em Educação Escolar e Mestre em Televisão Digital pela Universidade Estadual Paulista "Júlio de Mesquita Filho" (UNESP). MBA em Marketing na Fundação Getúlio Vargas (FGV). Docente do Centro Universitário Sagrado Coração (UNISAGRADO).

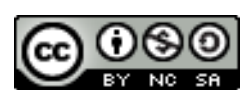

Esta obra está licenciada com uma Licença

Creative Commons Atribuição-NãoComercial-CompartilhaIgual 4.0 Internacional 